\title{
PEMBUATAN KOMPOSIT POLIMER SUPERABSORBEN DENGAN MESIN BERKAS ELEKTRON
}

\author{
DENI SWANTOMO, KARTINI MEGASARI, RANY SAPTAAJI \\ Sekolah Tinggi Teknologi Nuklir-BATAN \\ Jl. Babarsari Kotak Pos 1008, DIY 55010 \\ Telp. 0274.489716, Faks.489715
}

\begin{abstract}
Abstrak
PEMBUATAN KOMPOSIT POLIMER SUPERABSORBEN DENGAN MESIN BERKAS ELEKTRON. Polimer superabsorben adalah suatu polimer yang dapat mengabsorpsi air dan mempunyai daya serap sampai beberapa kali lipat dibandingkan berat polimernya. Polimer superabsorben dapat dimanfaatkan dalam banyak bidang diantaranya pembungkus makanan, teknik konstruksi, industri kimia, pengolahan limbah dan bahan pembuat sensor. Bahan utama polimer superabsorben adalah poliakrilamida. Poliakrilamida mempunyai kekurangan dalam kekuatan fisik dan kestabilan terhadap suhu. Dalam penelitian ini telah dilakukan pembuatan komposit polimer superabsorben menggunakan monomer akrilamida dan zeolit alam. Komposit polimer superabsorben dibuat dengan proses polimerisasi dan grafting akrilamida dengan zeolit alam menggunakan iradiasi mesin berkas elektron. Variabel yang dipelajari adalah dosis radiasi 15; 25; 28; 35; 48 kGy dan perbandingan akrilamida terhadap zeolit $0,5: 1 ; 1: 1$; 2:1. Bertambahnya dosis radiasi akan meningkatkan konversi komposit yang dihasilkan dan kapasitas absorpsi polimer superabsorben. Setelah tercapai ikatan polimer yang sempurna, penambahan dosis radiasi akan menurunkan kapasitas absorpsi. Semakin besar perbandingan akrilamida terhadap zeolit akan menaikkan konversi komposit yang dihasilkan dan kapasitas absorpsi.
\end{abstract}

Kata kunci : grafting, iradiasi pengion, komposit polimer superabsorben

\begin{abstract}
PREPARATION OF SUPERABSORBENT POLYMER COMPOSITE USING ELECTRON BEAM MACHINE. Superabsorbent polymer is a polymer that can absorp water up to several times of its own weight and keep this water. Because of these unique properties, superabsorbent polymer have potential applications in various areas for example in food packing, civil engineering, chemical industry plant, waste treatment and sensor materials. The main part of this materials is polyacrylamide. Polyacrylamide have lack properties like not good in mechanical strength and thermal stability. In this research have been conducted about the preparation of superabsorbent polymer composite using polyacrylamide and natural zeolite. Superabsorbent Polymer composite was prepared by polymerizing
\end{abstract}


acrylamide and grafted zeolite using electron beam irradiation. Various important parameters such as effect of irradiation dose 15; 25; 28; 35; 48 kGy and effect of acrylamide and zeolite ratio $0,5: 1 ; 1: 1 ; 2: 1$ were studied. The increasing of the irradiation dose would increase conversion of composite and the water absorption capacity but the water absorption capacity would be decrease after equilibrium reaction. The increasing of acrylamide and zeolite ratio would increase conversion of composite and absorption capacity

Keywords : grafting, ionizing irradiation, superabsorbent polymer composite

\section{PENDAHULUAN}

Dalam satu dekade terakhir ini, penelitian mengenai hidrogel telah mengalami berbagai kemajuan. Penggunaan hidrogel dapat dimanfaatkan dalam berbagai bidang diantaranya sebagai bahan polimer superabsorben. Kelebihan penggunaan hidrogel jika dibandingkan dengan bahan absorben lain seperti kertas, selulosa dan kapas adalah kemampuan absorpsinya beberapa kali lipat dibandingkan beratnya, tahan terhadap tekanan dan $90 \%$ bahannya dapat diuraikan sehingga ramah lingkungan. ${ }^{[1]}$

Polimer superabsorben adalah suatu bahan yang dapat mengabsorpsi dan atau menyimpan cairan lebih dari berat bahan tersebut dan tidak melepas cairan tersebut. ${ }^{[2]}$ Penggunaan polimer superabsorben sangat banyak diantaranya digunakan sebagai bahan pengolahan limbah, media tumbuh tanaman, bahan untuk mengurangi friksi dalam pipa, bahan pelapis anti bocor, pelindung jaringan kabel bawah tanah, bahan pembuatan kemasan barang dan bahan pemadam kebakaran. Polimer superabsorben dari bahan organik memiliki beberapa kelemahan diantaranya kapasitas absorpsi yang terbatas, karakteristik fisik yang kurang kuat, tidak stabil terhadap perubahan suhu dan $\mathrm{pH}$. Banyak penelitian yang dilakukan untuk memodifikasi polimer dengan bahan lain untuk meningkatkan kemampuan absorpsi dan ketahanan sifat fisiknya dengan memanfaatkan radiasi. ${ }^{[3]}$ melakukan penelitian pembuatan polimer superabsorben yang dimodifikasi dengan bentonit menggunakan radiasi gamma. Polimer yang dihasilkan mempunyai kapasitas absorpsi air dan uap yang lebih baik yaitu $200 \mathrm{~g}$ air/g polimer, ketahanan fisik terhadap suhu dan keasaman yang cukup tinggi. Menurut ${ }^{[4]}$, polimer superabsorben acrilamida dapat dimodifikasi dengan asam maleat dengan radiasi gamma. Polimer yang dihasilkan dapat mengabsorpsi larutan urea dengan kapasitas absorpsi antara 935 sampai 5212 g/g polimer. Hidrogel poliacrilnitril-maizena mempunyai kapasitas absorpsi $920 \mathrm{~g} / \mathrm{g}$ polimer. ${ }^{[5]}$

Dalam penelitian ini dilakukan proses pembuatan komposit polimer superabsorben poliacrilamida-zeolit alam dengan menggunakan mesin berkas 
elektron. Variabel yang diteliti adalah pengaruh dosis radiasi dan perbandingan berat akrilamida dengan zeolit alam.

\section{DASAR TEORI}

\section{Polimer Superabsorben}

Pada awalnya polimer superabsorben dibuat dari tepung, selulosa dan polivinil alkohol yang mempunyai gugus hidrofilik dan mempunyai daya afinitas yang tinggi terhadap air. Polimer superabsorben jenis ini mempunyai beberapa kelemahan diantaranya kapasitas absorpsinya relatif kecil, kurang stabil terhadap perubahan $\mathrm{pH}$, suhu dan sifat fisik yang tidak bagus. Dewasa ini sedang dikembangkan polimer superabsorben yang dibuat dari polimer organik yang dimodifikasi dengan mineral alam seperti bentonit, kuarsa dan silika. Polimer superabsorben modifikasi ini mempunyai sifat fisik dan kimia yang jauh lebih baik.

Polimer superabsorben dapat diklasifikasikan menjadi beberapa jenis. Berdasarkan morfologinya diklasifikasikan menjadi polimer superabsorben serbuk, partikel, bola, serat, membran dan emulsi. Ditinjau dari jenis bahan penyusunnya terdiri dari polimer superabsorben makromolekul alam, semipolimer sintetis dan polimer sintetis sedangkan dilihat dari proses pembuatannya dapat dibedakan menjadi polimer cangkokan dan polimer ikatan silang. ${ }^{[3]}$

Ikatan utama polimer superabsorben adalah gugus hidrofilik karena terdiri dari gugus asam karboksilat (-COOH) yang mudah menyerap air. Ketika polimer superabsorben dimasukkan dalam air atau pelarut akan terjadi interaksi antara polimer dengan molekul air. Interaksi yang terjadi adalah hidrasi. Mekanisme hidrasi yang terjadi adalah ion dari zat terlarut dalam polimer seperti $\mathrm{COO}^{-}$dan $\mathrm{Na}^{+}$akan tertarik dengan molekul polar air seperti pada Gambar $1 .^{[6]}$
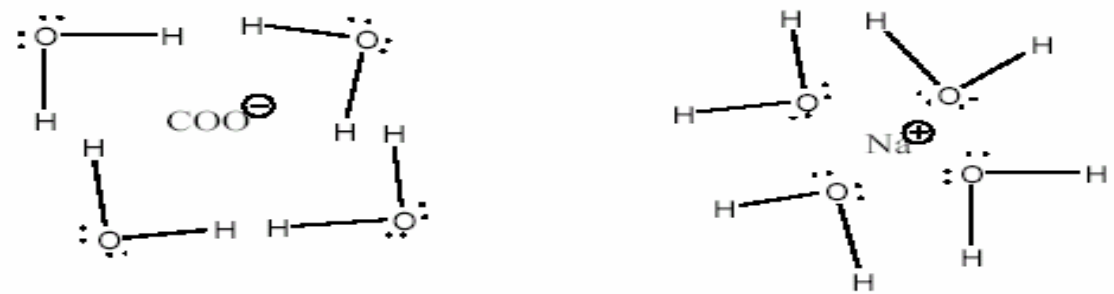

Gambar 1. Mekanisme Hidrasi Polimer Superabsorben

Adanya ikatan silang dalam polimer superabsorben menyebabkan polimer tidak larut dalam air atau pelarut. 


\section{Pembuatan Komposit Polimer Superabsorben}

Dalam proses pembuatan polimer superabsorben, polimer yang digunakan harus memenuhi persyaratan diantaranya yaitu bersifat hidrofilik, tidak larut dalam air, mempunyai gugus fungsi yang bersifat ionik. Asam poliacrilite dan poliacrilamide merupakan bahan polimer superabsorben yang paling banyak digunakan karena mempunyai daya afinitas yang paling baik. Pada Gambar 2, dapat dilihat bahwa poliacrilamida dan asam poliacrilite mempunyai gugus rantai aktif (R) yang dapat digunakan untuk proses grafting. Pada proses grafting, gugus aktif ini akan digunakan untuk berikatan dengan silika.

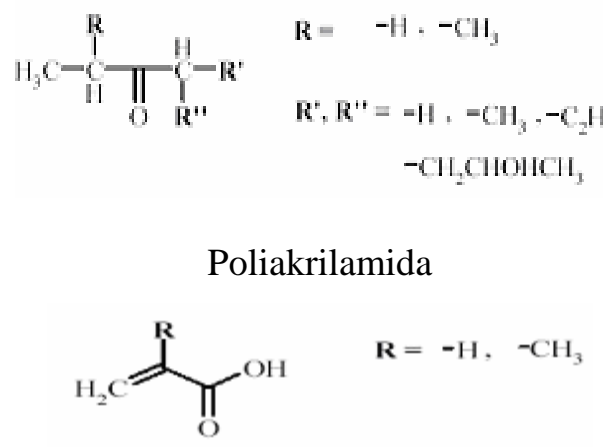

Asam Poliakrilat

Gambar 2. Poliacrilamida dan Asam Poliakrilat

Komposit polimer superabsorben dapat dibuat dengan proses penggabungan polimer dengan silika. Berdasarkan proses penggabungan, pembuatan polimer superabsorben dapat dibedakan menjadi dua jenis. Jenis pertama yaitu penggabungan monomer dengan silika kemudian diikuti proses polimerisasi sedangkan yang kedua adalah penggabungan polimer dengan silika. Proses pembuatan yang paling banyak digunakan adalah proses pertama karena dapat menghasilkan ikatan yang kuat antara polimer dengan silika.

Proses pembuatan polimer superabsorben dapat dilakukan dengan proses polimerisasi dengan menggunakan radiasi pengion. Polimerisasi dengan radiasi pengion mempunyai banyak keuntungan diantaranya tidak memerlukan bahan kimia adiktif sehingga tingkat kemurnian bisa lebih tinggi dan lebih ekonomis. Proses polimerisasi dengan radiasi pengion bisa dibagi menjadi tiga tahap, yaitu tahap inisiasi, propagasi dan terminasi. ${ }^{[7]}$ Peran radiasi pengion disini hanya terletak pada tahap inisiasi saja. Radikal bebas yang dihasilkan oleh radiasi pengion digunakan sebagai energi awal untuk 
memulai reaksi. Selanjutnya, reaksi polimerisasi berlanjut hingga tahap terminasi. Radikal yang dihasilkan oleh radiasi pengion relatif homogen walaupun melewati fase padat dan tidak mengalami kenaikkan suhu yang tinggi selama polimerisasi sehingga reaksinya mudah untuk dikontrol.

Proses polimerisasi terdiri dari : ${ }^{[8]}$

1. Tahap inisiasi : radikal bebas dihasilkan oleh radiasi pengion kemudian bereaksi dengan monomer yang belum jenuh.
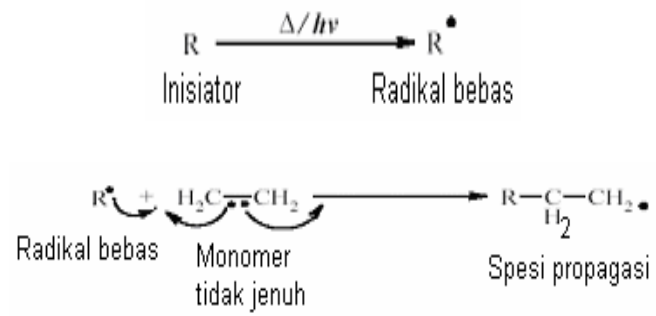

2. Tahap propagasi : pertumbuhan rantai polimer dengan terjadinya ikatan antara radikal propagasi dengan monomer.

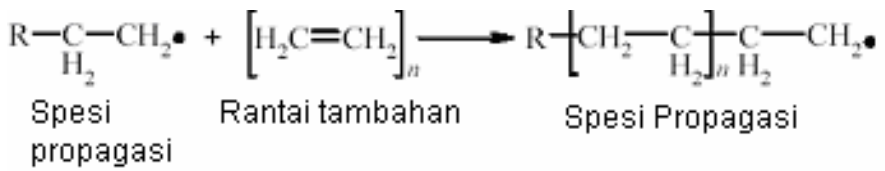

3. Tahap terminasi : pertumbuhan radikal propagasi sudah mengalami kejenuhan kemudian mulai melakukan reaksi penggabungan sampai mencapai keseimbangan dan reaksi berhenti.

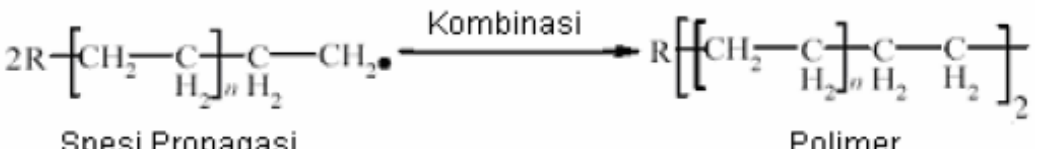

Spesi Propagasi

Polimer

Dari hasil studi literatur diperoleh informasi bahwa polimer superabsorben yang dibuat dari polimer organik mempunyai kelemahan yaitu kurang stabil terhadap perubahan suhu, keasaman, dan sifat fisik yang kurang bagus. Kelemahan polimer organik ini dapat diatasi dengan pembuatan polimer superabsorben dalam bentuk komposit. Komposit ini dapat dibuat dari grafting polimer dengan tepung ketela, tepung jagung maupun dengan mineral alam. Pembuatan komposit polimer superabsorben poliacrilamida dengan tepung ketela telah berhasil dilakukan oleh Suda Kiatkamjornwong dkk pada 2002. ${ }^{[1]}$

Komposit polimer superabsorben dengan mineral alam seperti bentonit, zeolit, sepiolit merupakan jenis komposit yang termasuk baru dikembangkan. Kelebihan komposit ini adalah mempunyai sifat elasitas dan 
permeabilitas polimer dengan kemampuan absorpsi berbagai jenis bahan yang dimiliki mineral alam. Mineral alam merupakan bahan yang banyak ditemukan di Indonesia dengan harga yang murah, seperti zeolit banyak terdapat di Gunung Kidul. Struktur molekul mineral alam mempunyai lapisan permukaan yang dapat dibuka pori-porinya atau diaktifkan, kestabilan sifat fisik dan kimia yang sangat baik. Di Indonesia telah banyak dikembangkan mineral alam sebagai bahan filtrasi dan adsorpsi dalam pengolahan limbah.

Penggunaan mineral alam seperti zeolit dan bentonit mempunyai keterbatasan pada kapasitas absorpsi yang rendah. Pembuatan komposit polimer superabsorben dengan mineral alam diharapkan dapat menutupi kelemahan masing-masing komponen penyusunnya. ${ }^{[3]}$

Pembuatan komposit polimer superabsorben dapat dilakukan dengan proses grafting polimer dengan mineral alam dan proses penggabungan (intercalating) monomer dengan mineral alam kemudian diikuti proses polimerisasi. Proses grafting dapat dilakukan dengan metode kimia, yaitu dengan menggunakan bahan kimia inisiator polimerisasi, dan bahan pembentuk ikatan silang (crosslinker). Bahan inisiator yang sering digunakan adalah amonium perokdisulfat sedangkan bahan pembentuk ikatan silang yang digunakan yaitu trimetil propana triacrilate, 1,4-butadienol dimetacrilate dan N,N'-metilene bisacrilamide. Penambahan aktivator N,N,N',N'tetrametiletilendiamine diperlukan untuk mempercepat reaksi polimerisasi. Proses grafting ini juga masih membutuhkan pemanasan dari luar.

Proses lain dalam pembuatan komposit polimer superabsorben-mineral lokal adalah dengan metode grafting menggunakan radiasi pengion. Metode ini mempunyai beberapa kelebihan jika dibandingkan dengan metode kimia, yaitu : proses grafting dapat dilakukan pada monomer fase padat, cair, atau gas; tidak membutuhkan penambahan bahan kimia seperti inisiator, crosslinker, maupun aktivator sehingga produk yang diperoleh lebih murni; tidak memerlukan penambahan panas dan reaksinya mudah dikendalikan. Ada dua sumber radiasi yang sering digunakan dalam proses grafting yaitu sumber radiasi gamma dan elektron.

Proses grafting dengan irradiasi elektron dari Mesin Berkas Elektron (MBE) mempunyai beberapa kelebihan dibandingkan dengan irradiasi gamma, diantaranya adalah kapasitas pemrosesan besar, luasan bahan yang akan digrafting dapat dikendalikan, efisiensi pemanfaatan energi yang tinggi, dan keselamatan radiasi yang aman. 


\section{METODOLOGI PENELITIAN}

\section{Bahan}

Bahan yang digunakan dalam penelitian ini antara lain: monomer acrilamida, zeolit alam, akuades, metanol teknis.

\section{Peralatan}

Peralatan yang digunakan dalam penelitian ini antara lain: seperangkat alat gelas, pemanas magnetic stirrer, pipet volume, termometer, oven, stop watch, Mesin Berkas Elektron (MBE), FTIR, dan SEM.

\section{Cara Kerja}

\section{a. Proses gelatin zeolit}

Dua puluh gram zeolit alam dicampur dengan $200 \mathrm{ml}$ akuades, diaduk sambil dipanaskan pada suhu $85^{\circ} \mathrm{C}$ selama 1 jam.

b. Pengaruh dosis radiasi

Gelatin zeolit didinginkan pada suhu kamar kemudian ditambahkan $10 \mathrm{~g}$ acrilamida sambil diaduk 400 rpm pada suhu kamar 30 menit. Campuran tersebut dimasukkan ke dalam wadah sampel. Sampel diiradiasi dengan Mesin Berkas Elektron dengan variasi dosis radiasi 15, 25, 28, 35, dan 48 kGy. Sampel yang telah diiradiasi kemudian dicuci dengan akuades dan dikeringkan dengan metanol kemudian dikeringkan dengan oven pada suhu $85{ }^{\circ} \mathrm{C}$ selama 24 jam. Sampel kering dihaluskan menjadi bubuk dimasukkan dalam akuades dan diaduk selama 8 jam pada suhu kamar. Campuran tersebut dipisahkan antara homopolimer dengan kopolimer bebasnya dengan centrifuge.

c. Pengaruh rasio monomer acrilamida dengan zeolit

Dibuat variasi acrilamida dengan zeolit 0,5:1; 1:1; 2:1. Gelatin campuran tersebut diiradiasi dengan Mesin Berkas Elektron pada dosis optimumnya. Komposit polimer superabsorben yang dihasilkan dikarakterisasi dan dilakukan pengujian kapasitas absorpsi.

d. Karakterisasi polimer

1. Identifikasi ikatan dalam komposit polimer superabsorben menggunakan FTIR

2. Identifikasi komposisi komposit polimer superabsorben menggunakan SEM.

3. Penentuan persentase konversi homopolimer yang dihasilkan dengan gravimetri.

$$
\% \text { konversi }=\frac{\text { berat } \text { komposit }}{\text { berat bahan }} \times 100
$$


4. Penentuan kapasitas absorpsi :

Akuades ditambahkan pada polimer superabsorben dan dibiarkan selama 60 menit untuk proses penggembungan (swelling). Polimer yang telah menggembung disaring dan ditimbang. Air yang tidak terserap untuk menentukan kapasitas absorpsinya.

$$
\text { kapasitas absorpsi }=\frac{\mathrm{M}_{\mathrm{t}}-\mathrm{M}_{0}}{\mathrm{M}_{0}}
$$

Dengan :

$\mathrm{M}_{\mathrm{t}} \quad$ : berat komposit superabsorben setelah proses penggembungan selama waktu t menit

$\mathrm{M}_{0} \quad$ : berat komposit superabsorben awal

HASIL

Tabel 1. Pengaruh Dosis Radiasi (10 gram akrilamida : 20 gram zeolit)

\begin{tabular}{ccccc}
\hline No & $\begin{array}{c}\text { Dosis } \\
\text { Radiasi } \\
(\mathrm{kGy})\end{array}$ & $\begin{array}{c}\text { Berat komposit polimer } \\
\text { superabsorben (gram) }\end{array}$ & $\begin{array}{c}\text { Persen konversi hasil } \\
\text { komposit polimer } \\
\text { superabsorben (\%) }\end{array}$ & $\begin{array}{c}\text { Kapasitas } \\
\text { absorpsi }\end{array}$ \\
\hline 1 & 15 & 22,0092 & 73,364 & 89,6 \\
2 & 25 & 25,6071 & 85,357 & 102,5 \\
3 & 28 & 27,8650 & 92,883 & 103,4 \\
4 & 35 & 28,0080 & 93,360 & 110,8 \\
5 & 48 & 28,0234 & 93,411 & 105,6 \\
\hline
\end{tabular}

Tabel 2. Pengaruh Rasio Monomer Akrilamida Dengan Zeolit pada Dosis Radiasi 35 kGy

\begin{tabular}{ccccc}
\hline No & $\begin{array}{c}\text { Rasio } \\
\text { acrilamida : } \\
\text { zeolit }\end{array}$ & $\begin{array}{c}\text { Berat komposit polimer } \\
\text { superabsorben (gram) }\end{array}$ & $\begin{array}{c}\text { Persen konversi hasil } \\
\text { komposit polimer } \\
\text { superabsorben (\%) }\end{array}$ & $\begin{array}{c}\text { Kapasitas } \\
\text { absorpsi }\end{array}$ \\
\hline 1 & $0,5: 1$ & 28,0080 & 93,360 & 110,8 \\
2 & $1: 1$ & 28,5072 & 95,024 & 115,7 \\
3 & $2: 1$ & 29,3480 & 97,827 & 115,9 \\
\hline
\end{tabular}

\section{PEMBAHASAN}

Proses pembuatan komposit polimer superabsorben dimulai dengan proses intercalating monomer acrilamida dengan struktur permukaan mineral zeolit alam yang komponen utamanya silikat. Mineral alam mempunyai struktur pori-pori permukaan yang dapat dibuka atau diaktifkan sehingga memungkinkan molekul monomer dapat masuk dalam struktur tersebut. 
Campuran monomer dengan mineral lokal kemudian diiradiasi dengan Mesin Berkas Elektron sehingga terjadi polimerisasi simultan seperti ditunjukkan pada Gambar 3.

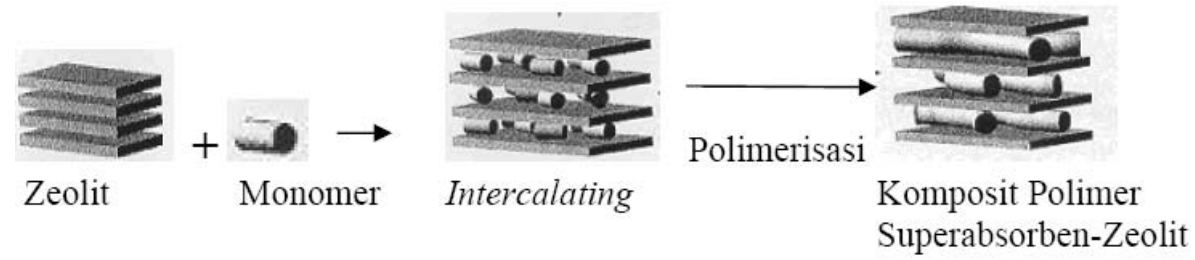

Gambar 3. Proses Pembuatan Komposit Polimer Superabsorben

Gambar 4 menunjukkan hasil analisis SEM pada sampel komposit superabsorben poliacrilamida-zeolit.
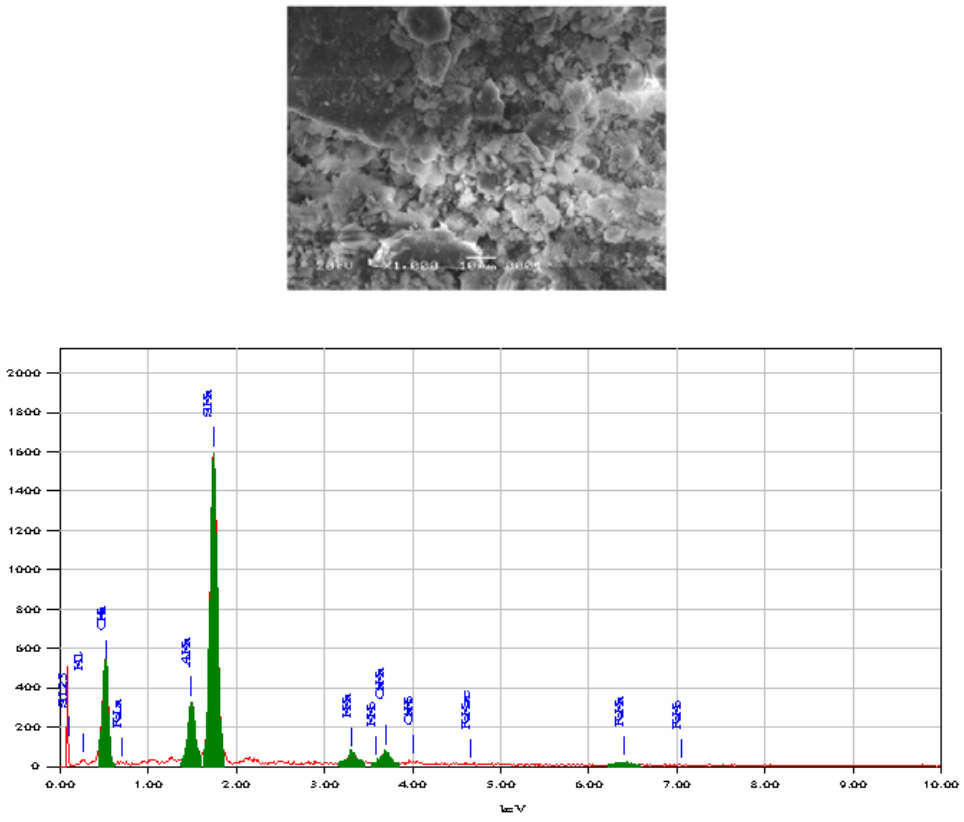

Gambar 4. Hasil Analisis SEM Komposit Superabsorben PoliakrilamidaZeolit

Berdasarkan gambar di atas dapat dilihat komposisi komposit poliacrilamidazeolit diantaranya terdiri dari komponen $\mathrm{C}-\mathrm{H}, \mathrm{Al}_{2} \mathrm{O}_{3}, \mathrm{SiO}_{2}, \mathrm{FeO}$. Hal ini membuktikan bahwa dalam struktur komposit mengandung komponen organik dari poliacrilamida dan komponen anorganik seperti $\mathrm{SiO}_{2}, \mathrm{Al}_{2} \mathrm{O}_{3}$ yang berasal dari zeolit alam. 
Gambar 5 menunjukkan hasil analisis FTIR pada sampel komposit superabsorben poliacrilamida-zeolit.

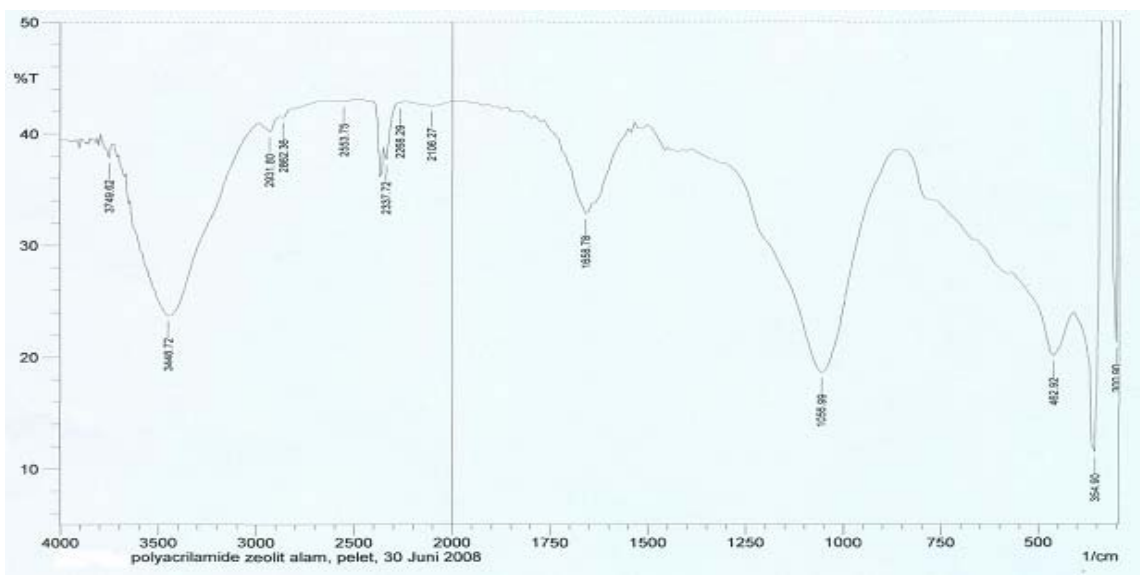

Gambar 5. Hasil Analisis FTIR Komposit Superabsorben Poliakrilamida-Zeolit

Berdasarkan gambar di atas dapat dilihat bahwa puncak lebar yang jelas pada frekuensi $1056 \mathrm{~cm}^{-1}$ yang terletak pada kisaran frekuensi untuk ikatan gugus fungsional Si-OCH $\mathrm{H}_{3}$. Hal ini menunjukkan bahwa dalam komposit tersebut mengandung $\mathrm{SiO}_{2}$ dari komponen zeolit alam yang telah berikatan dengan komponen organik poliacrilamida. Gugus fungsional asam karboksilat ($\mathrm{COOH}$ ) yang merupakan gugus utama polimer superabsorben juga terlihat pada frekuensi $2931 \mathrm{~cm}^{-1}$.

Polimer superabsorben yang telah dihasilkan dilakukan uji absorpsi untuk menentukan kapasitas absorpsinya. Uji kapasitas absorpsi dilakukan dengan jalan memasukan polimer superabsorben ke dalam pelarut air. Polimer superabsorben akan mengalami penggembungan seperti pada Gambar 6.
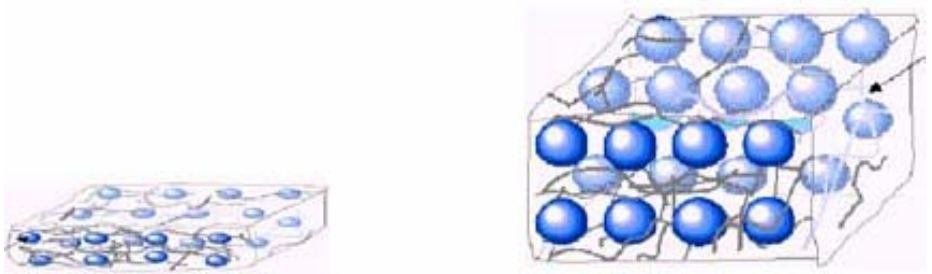

Gambar 6. Proses Penggembungan Polimer Superabsorben

Air akan terdifusi oleh polimer superabsorben karena adanya gugus hidrofilik. Setelah mencapai tahap kesetimbangan, air yang terserap akan 
terikat dengan gugus karboksilat membentuk ikatan hidrogen. Pada akhirnya air yang terserap akan tetap tertahan pada polimer superabsorben sehingga polimer mengalami penggembungan.

\section{Pengaruh Dosis Radiasi}

Pengaruh dosis radiasi sangat berpengaruh pada konversi monomer yang membentuk polimer dan jumlah ikatan silangnya. Pengaruh dosis radiasi terhadap persentase konversi komposit digambarkan pada Gambar 7.

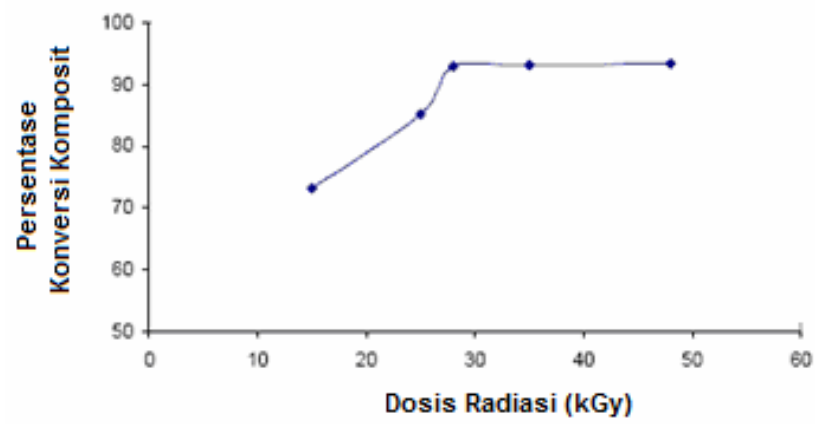

Gambar 7. Hubungan Antara Dosis Radiasi dengan Persentase Konversi Komposit

Bertambahnya dosis radiasi akan meningkatkan persentase konversi komposit. Energi radiasi pengion digunakan sebagai energi awal untuk memulai reaksi polimerisasi. Kenaikkan dosis radiasi akan meningkatkan densitas radikal bebas yang dihasilkan sehingga probabilitas reaksi polimerisasi akan semakin tinggi.

Pengaruh dosis radiasi terhadap kapasitas absorpsi komposit polimer superabsorben digambarkan pada Gambar 8.

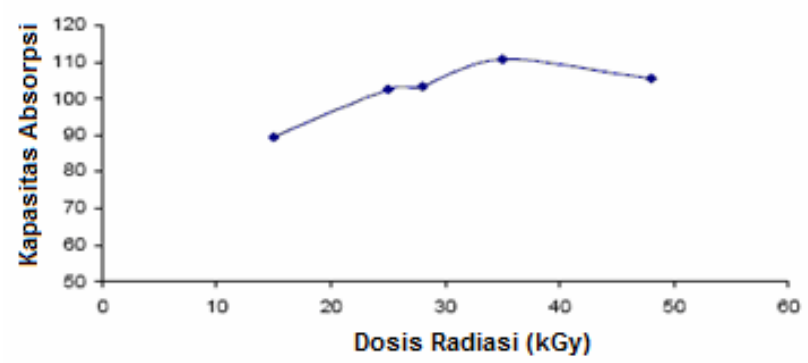

Gambar 8. Hubungan Antara Dosis Radiasi dengan Kapasitas Absorpsi

Bertambahnya dosis radiasi akan meningkatkan kapasitas absorpsi komposit polimer superabsorben. Hal ini karena struktur komposit polimer superabsorben akan semakin sempurna dengan bertambahnya dosis radiasi. 
Setelah tercapai ikatan komposit polimer yang sempurna, penambahan dosis radiasi justru akan menurunkan kapasitas absorpsi. Hal ini disebabkan kenaikkan dosis radiasi akan meningkatkan gel yang terbentuk sehingga ikatan silang polimer superabsorben semakin banyak dan akan menurunkan kemampuan absorpsinya.

\section{Pengaruh Perbandingan Monomer Akrilamida terhadap Zeolit}

Pengaruh perbandingan monomer acrilamida dengan zeolit dilakukan pada dosis radiasi 35 kGy. Penambahan zeolit bertujuan untuk memperbaiki sifat fisik dan kestabilan polimer superabsorben terhadap perubahan suhu dan keasaman.

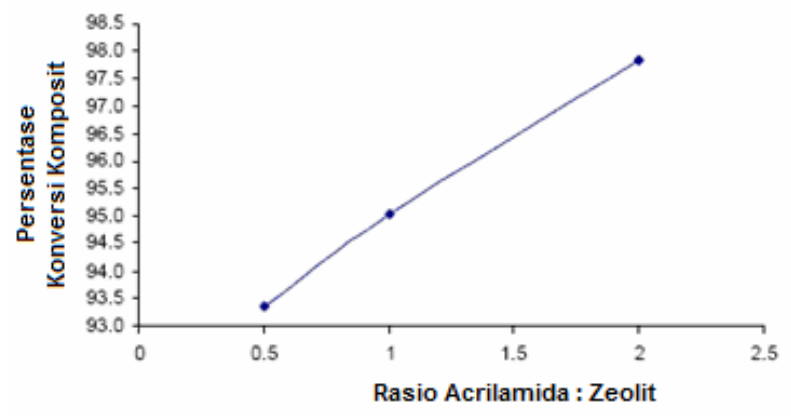

Gambar 9. Hubungan Antara Perbandingan Akrilamida Terhadap Zeolit dengan Persentase Konversi Komposit

Berdasarkan Gambar 9 menunjukkan bahwa semakin besar perbandingan acrilamida terhadap zeolit akan meningkatkan persentase konversi komposit. Hal ini disebabkan semakin besar kandungan acrilamida maka gugus rantai aktif (R) yang dapat digunakan untuk proses grafting akan semakin banyak juga. Pada proses grafting, gugus aktif ini akan digunakan untuk berikatan dengan zeolit.

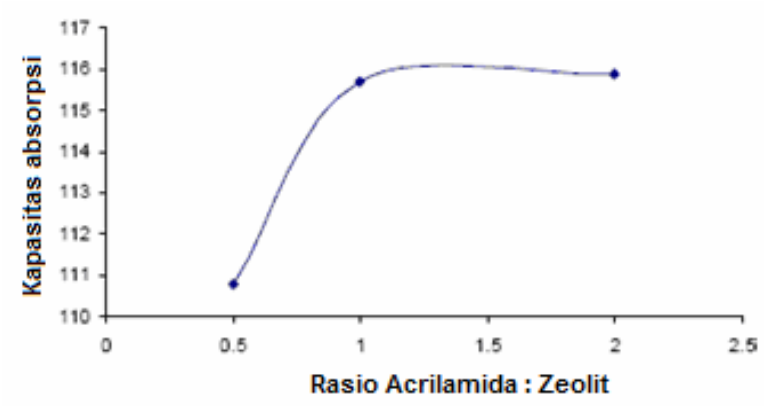

Gambar 10 Hubungan Antara Perbandingan Akrilamida

Terhadap Zeolit dengan Kapasitas Absorpsi 
Pengaruh perbandingan akrilamida terhadap zeolit terhadap kapasitas absorpsi komposit polimer superabsorben digambarkan pada Gambar 10. Berdasarkan Gambar 10 semakin besar rasio akrilamida terhadap zeolit maka semakin besar juga kapasitas absorpsi komposit polimer superabsorben. Hal ini karena penambahan acrilamida dapat menambah jumlah gugus aktif yang digunakan untuk melakukan proses absorpsi. Penambahan zeolit akan menyebabkan kapasitas absorpsi polimer superabsorben menurun. Konsentrasi zeolit yang semakin besar menyebabkan acrilamide tidak mampu lagi berikatan silang dengan zeolit sehingga struktur polimer superabsorben akan rusak dan mengganggu kemampuan absorpsinya. Penambahan zeolit tetap diperlukan dalam konsentrasi tertentu untuk meningkatkan sifat fisik polimer superabsorben.

\section{KESIMPULAN}

1. Polimer superabsorben adalah suatu bahan yang dapat mengabsorpsi air dan menyimpannya dalam jumlah yang besar.

2. Komposit polimer superabsorben dapat dibuat dengan proses grafting polimerisasi antara poliacrilamide dengan zeolit alam menggunakan radiasi pengion dari mesin berkas elektron.

3. Bertambahnya dosis radiasi akan meningkatkan persentase konversi komposit yang dihasilkan dan menaikkan kapasitas absorpsi polimer superabsorben. Setelah tercapai ikatan polimer yang sempurna, penambahan dosis radiasi akan menurunkan kapasitas absorpsi.

4. Semakin besar perbandingan acrilamida terhadap zeolit persentase konversi komposit yang dihasilkan dan menaikkan kapasitas absorpsi. Penambahan zeolit bertujuan untuk memperbaiki sifat fisik dan kestabilan polimer superabsorben.

\section{DAFTAR PUSTAKA}

1. Suda Kiatkamjornwong, Kanlaya Mongkolsawat, Manit Sonsuk, 2002, "Synthesis and Property Characterization of Cassava Starch Grafted Polyacrylamide-Maleic Acid Superabsorbent via Gamma Irradiation”, Polymer Journal 43.

2. Mark Elliot, 1997, ”Superabsorbent Polymers”, BASF Product Development Scientist.

3. Dayo Gao, 2003, ”Superabsorbent Polymer Composite (SAPC) Materials and their Industrial and High-Tech Applications", Dissertation, Der Technischen U ät Bergakademie Fiberg University. 
4. Erdener Karadag, O“ mer Barýs_zu“m, Dursun Saraydýn, Olgun Gu“ven, 2006, "Swelling characterization of gamma-radiation induced crosslinked acrylamide/maleic acid hydrogels in urea solutions” Materials and Design Journals 27.

5. Guojie Wang, Min li, 1996, ”Inverse Suspension Polymerization of Sodium Acrylate” Institute of Materials Science, Jilin University, China.

6. Soo Cheong Chang dan Jin Sung Yoo, 1999, ”Measurement and Calculation of Swelling Equilibria for Water/Poly(Acrilamide-Sodiummallysufonate) Systems”, Korean Journals Chemical Engineering 16.

7. Jacek Dutkiewicz, 2002, "Some Advances in Nonwoven Structures for Absorbency, Comfort and Aesthetics”, AUTEX Research Journal Volume 2.

8. Donghwan Richie Kim dan Mohammad Abidian, 2004, "Synthesis and Characterization of Conducting Polymers Grown in Hydrogels for Neural Applications”, Material Research Proceeding Volume E 